\title{
Minimal late Holocene sea level rise in the Chukchi Sea: arctic insensitivity to global change?
}

\author{
Owen K. Mason $^{\mathrm{a}, *}$, James W. Jordan ${ }^{\mathrm{b}}$ \\ ${ }^{a}$ Alaska Quaternary Center, PO Box 756960, University of Alaska Museum, Fairbanks, AK 99775-6960, USA \\ ${ }^{\mathrm{b}}$ Department of Environmental Studies, Antioch New England Graduate School, Keene, NH 03431, USA
}

Received 28 February 2001; accepted 1 June 2001

\begin{abstract}
Long-term estimates of sea level rise are essential for planning responses to anthropogenic global change. The tectonically stable, unglaciated eastern Chukchi Sea coast has numerous depositional environments for extracting long-term records in the absence of tide gauge data. Radiocarbon ages $(n=27)$ on paleo-marsh beds along several Seward Peninsula lagoons allows the reconstruction of sea level over the last 6000 years in northwest Alaska and indicate a modest sea level rise, $\sim 1.5 \mathrm{~m}$, or 0.27 $\mathrm{mm} \mathrm{year}^{-1}$. Neoglacial (1600-200 cal BC) storm deposits from Kotzebue Sound to Barrow are 1-1.5 m below modern storm surge elevations, supporting the inference of a lower eustatic sea level. Our data-constrained sea level curve establishes that the Chukchi Sea responds at a considerably slower rate than other regions of the world, supporting recent models of isostatic response for the arctic. (C) 2002 Elsevier Science B.V. All rights reserved.
\end{abstract}

Keywords: Sea level change; Late Holocene; Global change; Alaska

\section{Introduction}

Global change modelers propose catastrophic scenarios for 21 st century sea level rise associated with anthropogenic burning of fossil fuels (Warrick and Oerlemans, 1990; Wigley and Raper, 1992; Nichols and Leatherman, 1995). The sensitivity of arctic coasts to Global Change is postulated by some researchers (Jorgenson and Ely, 1998; Sedinger, 1998). While globally averaged tide gauge records of eustatic sea level indicate that a rate of rise of about $1 \mathrm{~mm}_{\text {year }}{ }^{-1}$ has prevailed since 4000 BC (Emery and Aubrey, 1991,

\footnotetext{
${ }^{*}$ Corresponding author. Tel.: +1-907-336-0092; fax: +1-907336-0093.

E-mail address: afokm@uaa.alaska.edu (O.K. Mason).
}

p. 165; Douglas, 1991; Pirazzoli, 1991; Gornitz, 1993), long-term tide gauge data are lacking for western Alaska (Emery and Aubrey, 1991). Baseline data from the southern Chukchi Sea (Fig. 1) record that relative sea level has risen slowly during the late Holocene, at a rate substantially less than other regions (Jordan and Mason, 1999). Climatic factors also influence sea level over decades to centuries (Gornitz et al., 1982; van de Plassche et al., 1998; van de Plassche, 2000; Varekamp and Thomas, 1998) and influence the morphology and erosion potential of high latitude coasts.

\section{Northwest Alaska: seismic and isostatic stability}

Kotzebue Sound and Seward Peninsula lie within a moderately active seismogenic province connected to 


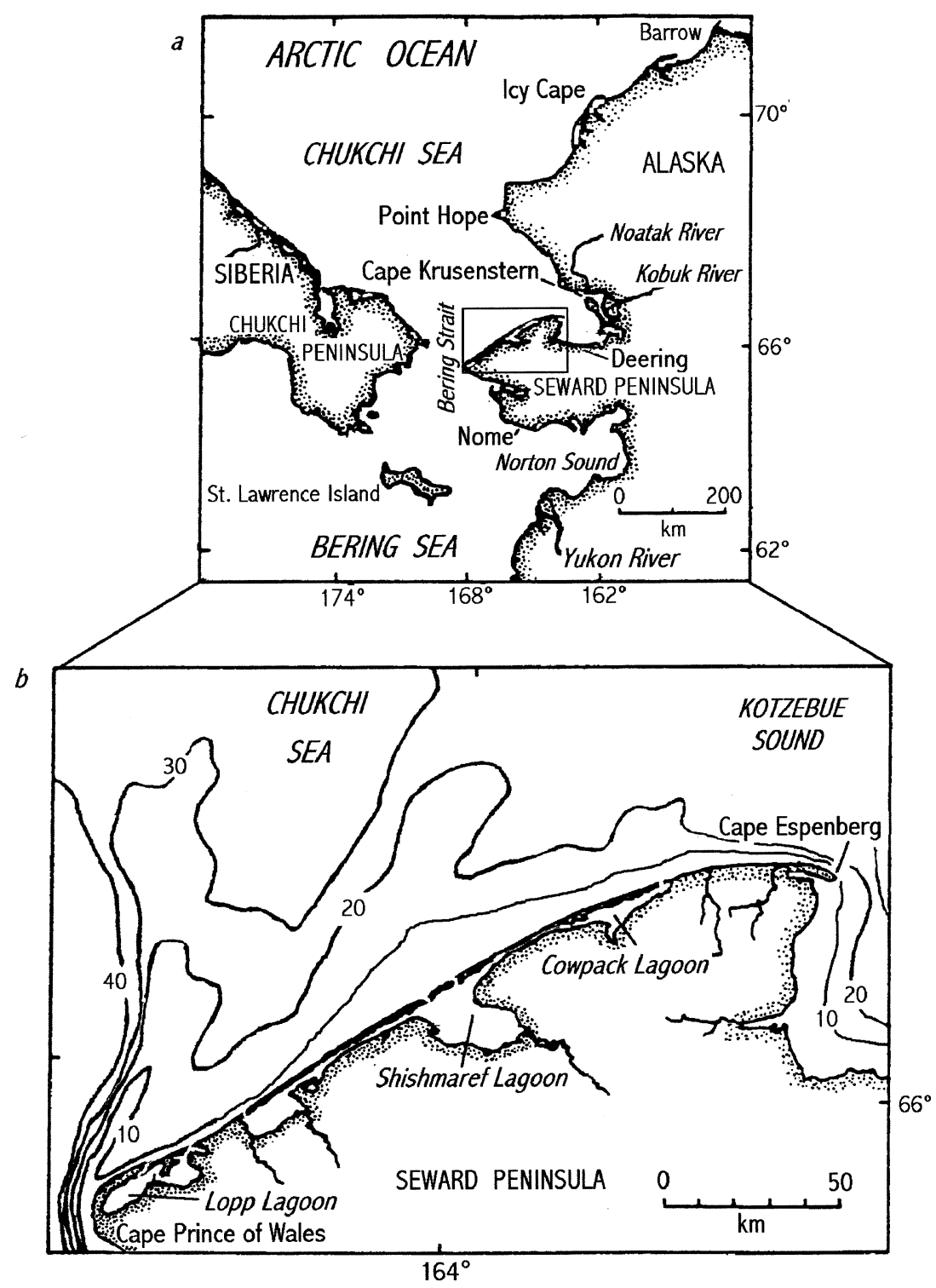

Fig. 1. Map of Bering Strait region (a) and northern Seward Peninsula (b), indicated by rectangle in (a). Bathymetry in (b) is in meters. The Shishmaref Barrier Island localities are seaward of Shishmaref Inlet (cf. Jordan and Mason, 1999 for locations of cores).

the Brooks Range (Eittreim et al., 1977; Thenhaus et al., 1982). Sporadic 20th century seismic activity is documented adjacent the eastern Chukchi Sea, with only two earthquakes of magnitude 5.0 to 6.0 during the last 70 years (Fujita et al., 1990). Despite this activity, co-seismic elevation changes are not detectable during the Holocene, as indicated by the position
(8-10 $\mathrm{m}$ above MSL) of the Last Interglacial (Isotope stage 5e) shoreline (Hamilton and Brigham-Grette, 1991, p. 64) that may reflect only several meters of uplift over 125,000 years. Some local subsidence is documented in southern Kotzebue Sound (BrighamGrette and Hopkins, 1995). Last Glacial Maximum $\left(18,000{ }^{14} \mathrm{C}\right.$ years $\left.\mathrm{BP}\right)$ glaciers were restricted to 
north-facing cirques in the southern Seward Peninsula along the Bering Sea near Nome (Kaufman and Hopkins, 1986, p. 70) and none of the coastal mountains, including the $<2000 \mathrm{~m}$ high western Brooks Range, produced any glaciers that extended even close to the Chukchi shore during the late Pleistocene or Holocene. Hence, isostatic compensation is not occurring, in accord with the model expectations of Clark and Lingle (1979, p. 295).

The continental shelf offshore from Seward Peninsula is shallow ( $<30 \mathrm{~m}$ deep) and covered by several meters of sand and silty sand (Creager and McManus, 1966), susceptible to reworking into barrier islands and spits by prevailing southerly currents entering the
Chukchi Sea through Bering Strait (Nelson and Creager, 1977; Naidu and Gardner, 1988). In sum, northwest Alaska has been stable throughout the Holocene and provides a reliable geologic setting for establishing the long-term eustatic trend of sea level.

\section{Paradigms of sea level rise in northwest Alaska}

\subsection{Recognizing eustatic sea level fluctuations}

Relative sea level changes were first noted in western Alaska based on the subtidal elevations of archaeological middens along Saint Lawrence Island (Rainey,

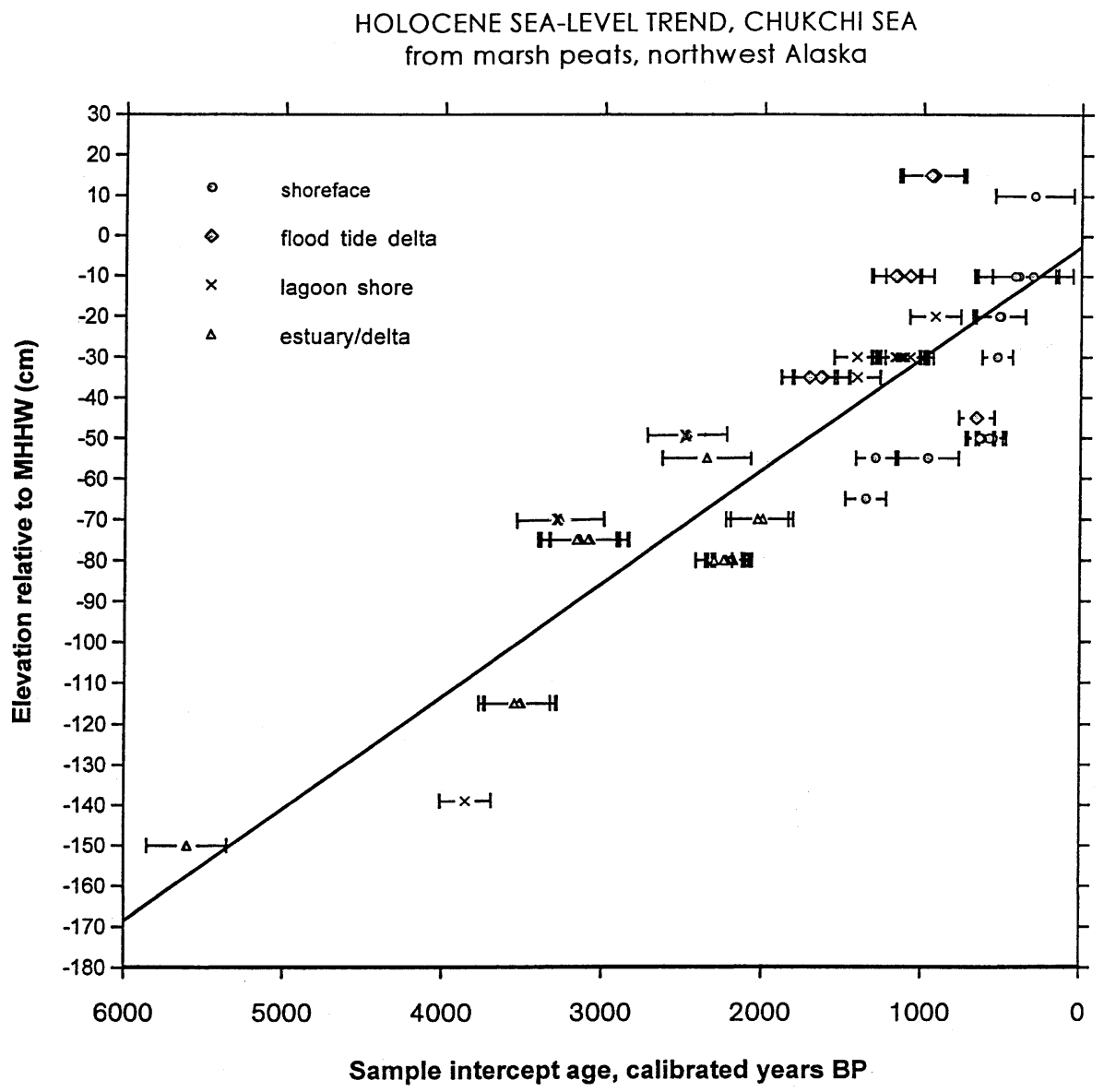

Fig. 2. Late Holocene sea level trend for the southern Chukchi Sea, based on radiocarbon-dated marsh peat samples from flood-tide delta, lagoon, deltaic and shoreface contexts between Lopp and Cowpack Lagoons. A least-squares trendline through data points indicates a long-term rate of sea level rise of about $0.3 \mathrm{~mm}_{\text {year }}{ }^{-1}$ (cf. Jordan and Mason, 1999). We assume peat compaction to have relatively little affect on trend, resulting in a vertical uncertainty of less than about $10 \mathrm{~cm}$ (Mason and Jordan, 1993; Mason et al., 1996; Mason, 1999). 
1941, p. 463). Subsided archaeological sites adjacent to lagoons near Barrow led Hume (1965, p. 1166) to infer a rapid rise of sea level rise, $0.5-1 \mathrm{~m}$, during (cal) $\mathrm{AD}$ $200-300$, based on ${ }^{14} \mathrm{C}$ ages (calibrated following Stuiver et al., 1998) on wood within beach ridges. Moore (1960) also proposed that northwest Alaska storm ridge elevation provided a proxy for eustatic sea level; however, such elevations are transient (Hume and Schalk, 1967) and must be tied to other sea level data planes (cf. Shennan et al., 1983; Taylor and Stone, 1996). Region-wide synchronous beach ridge formation, dated by archaeological limiting ages, cooccurred with sea level stabilization, and served to define the Holocene Krusensternian transgression (Hopkins, 1967, p. 83).

Salt marsh peats graded to mean high water were first employed by Jordan and Mason (1999) to extract a relative sea level curve. This paper extends those data by interpreting paleo-storm data points in relation to inferred sea level trend over the last 6000 years.

\subsection{Long-term records of sea level rise}

Oceanographic cores extracted from the continental shelf in the early 1960s allowed McManus and Creager (1984) to define post-glacial sea level rise. In this scenario, the Chukchi Sea was submerged first from the north ca. 18,000 BP and from the south, as the 40-m-deep Bering Strait flooded, ca. 14,500 BP based on bulk carbon samples (McManus and Creager, 1984). Improved radiometric dating and evidence from in situ terrestrial peat beds in the northern Chukchi Sea near Icy Cape demonstrate that the flooding of the Chukchi Platform and Bering Strait was post-dated 11,000 BP (Elias et al., 1992), concurrent with the entry of Pacific mollusca into western Canadian waters between 10,500-10,300 BP (Dyke et al., 1996, p. 167).

Oceanographic cores on the shelf do not provide fine scale resolution for sea level change after 5000 BP (McManus and Creager, 1984). Nonetheless, one core in a coastal lagoon near Barrow yielded driftwood dated to $7000-6000 \mathrm{BP}$ at the $-11 \mathrm{~m}$ datum (Faas, 1966). Terrestrial peat, presumably in situ, extracted by vibracore from Simpson Lagoon along the Beaufort Sea $250 \mathrm{~km}$ east of Barrow, may record a relative sea level $>3.5 \mathrm{~m}$ below present at $5000_{-}$ 4600 BP (Reimnitz in Trimble and Robinson, 1989, pp. 75-76). However, this elevation presents an anomaly in relation to data points from the Chukchi Sea (cf. Fig. 2) and, not surprisingly, reflects either local subsidence or a differing iso-eustatic response regime.

Fig. 3. (a) Aerial photographic montage of the Wales coastal plain reveals four lithostratigraphic units, oldest (I) to youngest (IV), using ${ }^{14} \mathrm{C}$ ages and geomorphic differences in thaw lake evolution, swale width, and the number of preserved ridges. ${ }^{14} \mathrm{C}$ data are presented in Table 1 from Profiles A and B illustrated in (b). Unit I contains large, globular lakes, abandoned lake basins and isolated dune residua. Unit II describes several closely spaced flat ridges, capped by thin peat beds that indicate the cutoff of beach sand. Unit III includes several low, narrow dune ridges separated by wide swales. Unit IV is a 3-4-m-high composite dune underlying the modern village and encloses a shallow, small lagoon. Unit IV built prior to a peat surface stabilized 1396-1520 AD (460 \pm 50 BP Beta-129590, R. Harritt, personal communication, 1999). Several beach ridges built along Lopp Lagoon, probably during the Little Ice Age (LIA ridges). (b) Lithological and peat stratigraphy along Lopp Lagoon (Fig. 1b), Wales beach ridge complex. Profile A extends $1.4 \mathrm{~m}$ below present MHHW, as marked by a thin pebbly sand (unit f) capping a 2-cm-thick peat on a 80-cm-high cutbank exposure on Lopp Lagoon. Exposed on the bank and from shallow cores are four massive very fine to fine sand beds separated by detrital beds of variable thickness and composition. The lowermost Unit a extends beneath $-1.4 \mathrm{~m}$ MHHW for an undetermined thickness. Units $b_{1}$ and $b_{2}$ describe two 5 -cm-thick sand beds intercalated between three thin $(2-5 \mathrm{~cm})$ peat beds, P-1. Unit $c$ is a massive, $45-\mathrm{cm}$-thick very fine to fine sand, probably emplaced by a single storm overwash event. Following this, a marsh developed, producing a $50-\mathrm{cm}$-thick, fibrous peat, P-2, intruded by a series of thin sand beds, Unit d. Peat P-3 describes a succeeding episode of marsh formation. A massive overwash sand, Unit e, covered this peat. Based on ${ }^{14} \mathrm{C}$ ages peat $\mathrm{P}-1$ formed between 2013 and 1686 cal BC, an upper limiting age on Unit a sedimentation, and a lower limiting age on the succeeding overwash deposit (Unit c). A 45-cm-thick series of peat beds between units $\mathrm{c}$ and $\mathrm{d}$ contain numerous thin sand stringers within a fibrous mass. Marsh development in Peat P-2 occurred during $1683-1127$ cal BC. The storm overwash that produced Unit d occurred after 757-204 cal BC (Beta-106959) and before 381 BC-22 AD (Beta-106960). Subsequently, a sand pulse of eolian or marine origin co-occurred with northerly Little Ice Age storms that eroded the lagoon margin. Profile B extends $80 \mathrm{~cm}$ into the crest of a stabilized dune and reveals five episodes (Units a to e) of dune activity interrupted by less windy periods in the early 1st millennium AD that allowed peat beds (in black) to form; peat between Units a/b grew ca. 1250 $\pm 60 \mathrm{BP}$ (Beta-98330), 665-905, $920-950 \mathrm{cal}$ AD. 


\section{Study area: the north Seward Peninsula coast}

Research from 1986 to 1994 concentrated within the northern Seward Peninsula depositional cell with its terminus and depositional sink at the Cape Espenberg spit (Mason, 1997; Mason and Jordan, 1993; Mason et al., 1995, 1997; Jordan and Mason, 1999). Data collected from Shishmaref Lagoon margin marsh peats led to the derivation of a sea level curve (Jordan and Mason, 1999). Data collected in 1996 from another depositional system at Cape Prince of Wales (Fig. 3) adds several sea level data points (Table 1,
Fig. 2) and extends the storm history documented at Cape Espenberg (Mason et al., 1997).

The recurved Wales coastal plain extends $25 \mathrm{~km}$ northeast from Cape Prince of Wales, the western extremity of Cape Mountain on the eastern margin of Bering Strait. The beach ridge plain includes two islands that enclose Lopp Lagoon, the most southern of a series of coastal lagoons on the north shore of Seward Peninsula (Creager and McManus, 1966). Composed of fine to medium sand, the Wales plain is a terrestrial analog to the large submarine shoal offshore from Bering Strait, which forms as intense

(a)

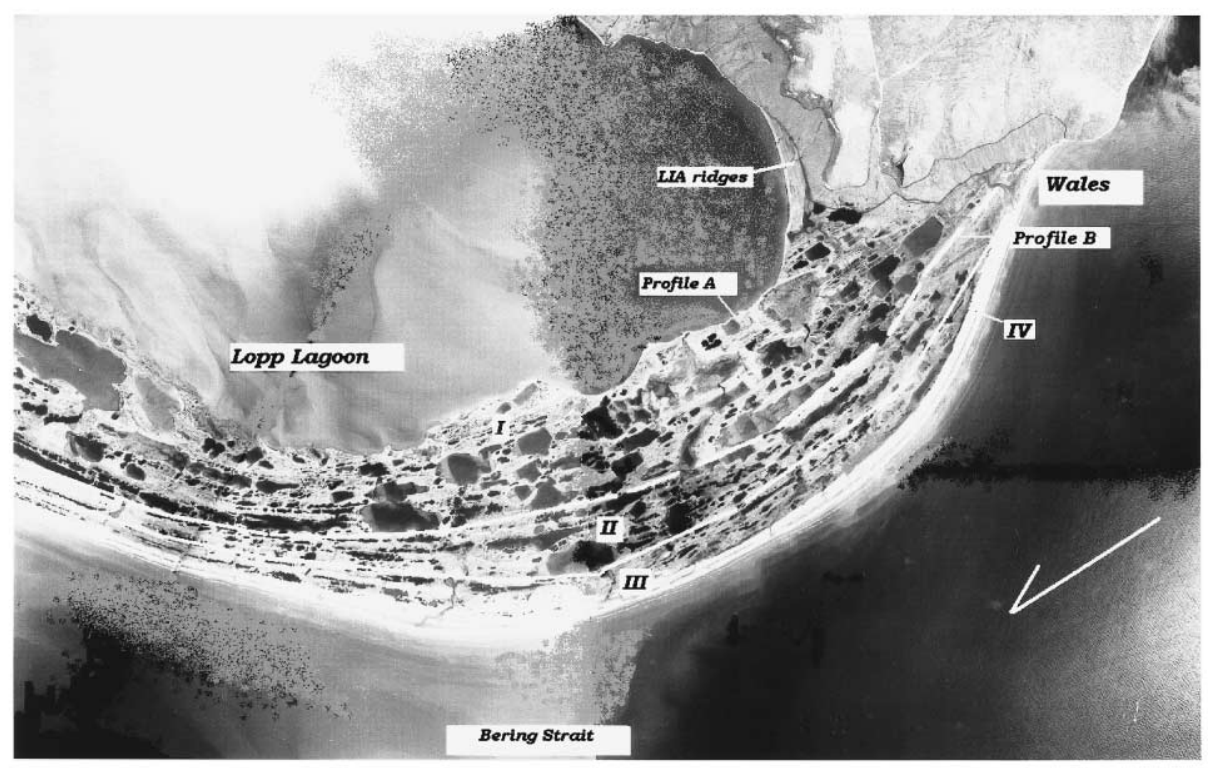

(b)

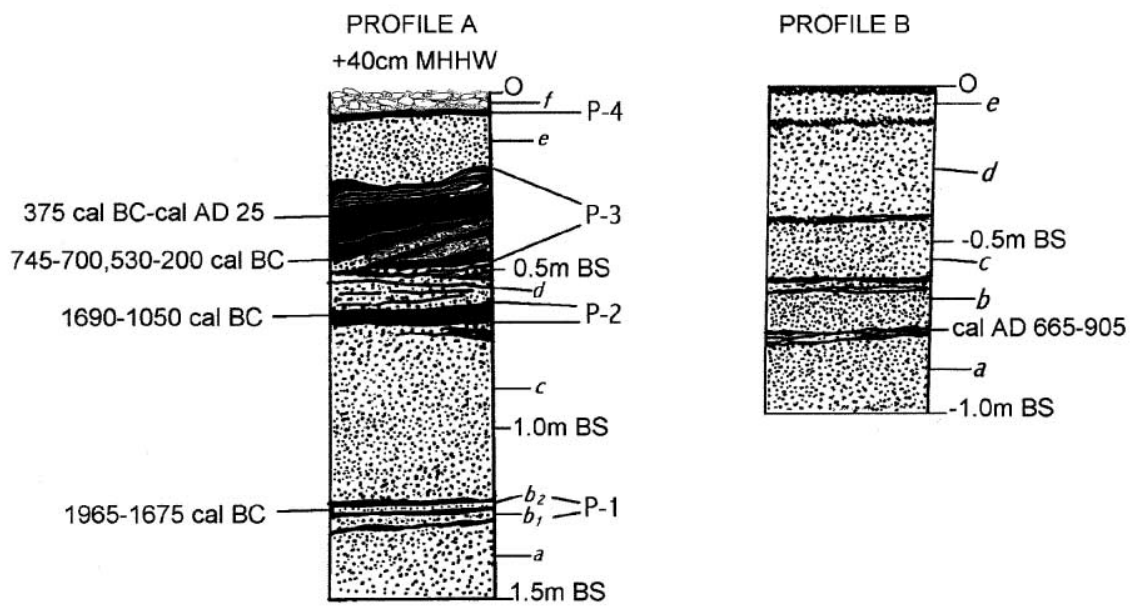


Table 1

Radiocarbon ages constraining the sea level history of the Chukchi Sea

\begin{tabular}{|c|c|c|c|c|c|}
\hline Lab no. & ${ }^{14} \mathrm{C}$ age & $\begin{array}{l}\text { Calibrated age } \\
\text { (BC/AD) }\end{array}$ & Context, material & $\begin{array}{l}\text { Elevation } \\
( \pm \text { MHHW) }\end{array}$ & Source \\
\hline \multicolumn{6}{|l|}{$\overline{\text { Wales }}$} \\
\hline Beta- 106960 & $2130 \pm 70$ & $381 \mathrm{BC}-22 \mathrm{AD}$ & Lagoon Marsh peat & $-0.5 \mathrm{~m}$ & this paper \\
\hline Beta-106959 & $2330 \pm 70$ & $757-204 \mathrm{BC}$ & Lagoon Marsh peat & $-0.5 \mathrm{~m}$ & this paper \\
\hline Beta-98334 & $3150 \pm 110$ & $1683-1127 \mathrm{BC}$ & Storm-dep. driftwood & $-0.75 \mathrm{~m}$ & this paper \\
\hline Beta-98333 & $3510 \pm 60$ & $2013-1686 \mathrm{BC}$ & Lagoon Marsh peat & $-1.0 \mathrm{~m}$ & this paper \\
\hline \multicolumn{6}{|c|}{ Cowpack Lagoon } \\
\hline Beta- 80205 & $3330 \pm 80$ & $1869-1431 \mathrm{BC}$ & Estuary/delta peat & $-1.15 \mathrm{~m}$ & Jordan and Mason, 1999 \\
\hline Beta- 80204 & $4870 \pm 70$ & $3787-3521 \mathrm{BC}$ & Estuary/delta peat & $-1.5 \mathrm{~m}$ & Jordan and Mason, 1999 \\
\hline \multicolumn{6}{|c|}{ Cape Espenberg } \\
\hline Beta-14158 & $1655 \pm 55^{*}$ & $1160-1439 \mathrm{AD}$ & Storm dep. shell & $+1.6 \mathrm{~m}$ & Mason et al., 1997 \\
\hline Beta-49162 & $2005 \pm 60 *$ & $773-1169 \mathrm{AD}$ & Storm dep. shell & $+1.0 \mathrm{~m}$ & Mason et al., 1997 \\
\hline Beta-76270 & $4540 \pm 90^{\circ}$ & $2332-1704 \mathrm{BC}$ & Storm dep. shell & $+0.4 \mathrm{~m}$ & Mason et al., 1997 \\
\hline Beta-76272 & $3270 \pm 70$ & $1735-1408 \mathrm{BC}$ & Storm dep. driftwood & $+0.7 \mathrm{~m}$ & Mason et al., 1997 \\
\hline Beta-79253 & $3280 \pm 80$ & $1741-1406 \mathrm{BC}$ & Storm dep. driftwood & $+0.9 \mathrm{~m}$ & Mason et al., 1997 \\
\hline \multicolumn{6}{|l|}{ Deering } \\
\hline Beta-113147 & $2230 \pm 60$ & $400-118 \mathrm{BC}$ & Storm-dep. driftwood & $+2.0 \mathrm{~m}$ & Reanier et al., 1998:10 \\
\hline Beta-113144 & $2860 \pm 80$ & $1290-830 \mathrm{BC}$ & Storm-dep. driftwood & $+1.3 \mathrm{~m}$ & Reanier et al., 1998: 21 \\
\hline \multicolumn{6}{|l|}{ Barrow } \\
\hline GX-380 & $1700 \pm 110$ & $78-601 \mathrm{AD}$ & Wood (Spit) & $+1.7 \mathrm{~m}$ & Péwé and Church, 1962 \\
\hline GX-381 & $2370 \pm 100$ & $792-200 \mathrm{BC}$ & Wood (Spit) & $+1.4 \mathrm{~m}$ & Péwé and Church, 1962 \\
\hline $\mathrm{I}-1868$ & $2650 \pm 160$ & $1251-397 \mathrm{BC}$ & Peat (barrier island) & $-0.25 \mathrm{~m}$ & Brown and Sellmann, 1966 \\
\hline I-1949 & $2860 \pm 140$ & $1412-794 \mathrm{BC}$ & Peat (barrier island) & $-0.75 \mathrm{~m}$ & Brown and Sellmann, 1966 \\
\hline I-1869 & $4570 \pm 130$ & $3641-2905 \mathrm{BC}$ & Peat (barrier island) & $-1.5 \mathrm{~m}$ & Brown and Sellmann, 1966 \\
\hline
\end{tabular}

Samples are calibrated via Stuiver et al. (1998), using a $510 \pm 57$ year correction for marine-carbon samples (cf. Dumond, 1998, p. 115). Other data points for Shishmaref Barriers are listed in Jordan and Mason (1999).

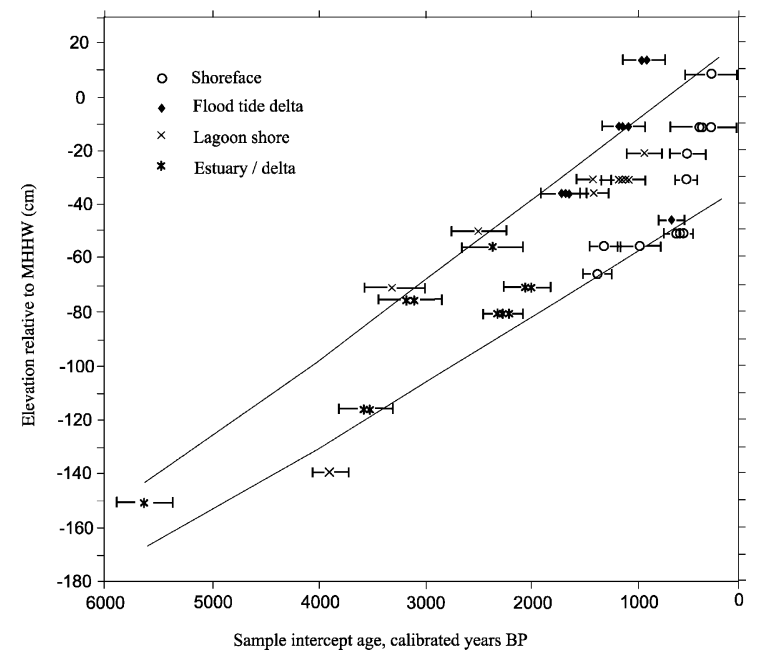


Bering Sea geostrophic currents lose strength after passage through the strait (Nelson and Creager, 1977). The shoal, $<10 \mathrm{~m}$ below the ocean surface, also acts as a sheltering embayment that traps fast ice and damps northerly and westerly storm waves. The sandy Wales beach ridge plain serves as an intermediate depositional sink for Norton Sound shelf sand derived from the Yukon River, much of which is carried farther into the southern Chukchi Sea, to be resuspended and transferred onshore into the Shishmaref barrier island chain (Nelson and Creager, 1977). The major input of sand into the Wales spit apparently followed the re-orientation of the Yukon Delta ca. 2500 years ago at the end of the Neoglacial expansion (Nelson, 1982; Dupré, 1982).

Several beach ridge complexes from Cape Espenberg to Point Barrow contain stratigraphic evidence of storm deposition at least $1 \mathrm{~m}$ below modern storm surge levels (Table 1). Radiocarbon-dated shell and driftwood from sections at Cape Espenberg occur on a ridge with a prominent erosional unconformity that indicates Neoglacial storms were of high magnitude. Radiocarbon-dated driftwood deposited by storms at Deering and Point Barrow also occurs at elevations lower than present surge elevations.

\section{Field methods}

\subsection{Depositional environments}

Several depositional environments are useful in inferring past sea level position along the northwest Alaska coast (Fig. 1), ranging from transgressed terrestrial and marsh peats, cultural midden deposits and prograding beach ridge and dune systems (van de Plassche, 1986; Shennan et al., 1983; Carter, 1988; Roep, 1986). Lagoon margin and deltaic locations provide the least biased estimates of paleo-sea level datum because storm effects are less frequent in these locations. Two settings produced consistent data: salttolerant marsh peat beds from small mainland deltas and flood tide deltas landward of the barrier islands. By contrast, beds of marsh peat exhumed along the active shoreface often varied vertically several tens of centimeters at scales of less than $5 \mathrm{~km}$; these disparities are difficult to extract from our sea level curves.

\subsection{Stratigraphic and chronometric analyses}

Shallow cores using an Oakfield soil probe were emplaced below dune and beach ridge facies to extend the record; this approach is constrained by ground water saturation. Measurements are referenced to Mean High High Water (MHHW), observed from field observations on the growth of salt tolerant Carex spp., the dominant tidal marsh species. Tidal range in the Chukchi Sea is generally $<0.5 \mathrm{~m}$, but can be displaced vertically $>3 \mathrm{~m}$ by transient storm surges, as in October 1963, the storm of record (Hume and Schalk, 1967).

Field research involved stratigraphic profiling of exposed cutbanks and shallow coring using radiocarbon ages to establish horizontal and vertical chronology. The linear trend of beach ridges was mapped from aerial photographs $(1: 30,000)$ archived by the Geo-Data Center of the Geophysical Institute (UAF), supplemented with 1:8000 imagery commissioned by the National Park Service from AeroMap, Inc. Stratigraphic sections recorded sedimentary structures and contacts, grain size, color alteration (Munsell charts) and macrofossils (charcoal, shell, grass and/or driftwood).

A series $(n=23)$ of radiocarbon ages on salt tolerant marsh peats along Shishmaref and Cowpack Lagoons enabled Jordan and Mason (1999) to derive a relative sea level curve for the Seward Peninsula. These data are supplemented here by additional radiocarbon ages from Wales $(n=4)$, Cape Espenberg $(n=5)$, Deering $(n=2)$ and Barrow $(n=5)$ (Table 1); only marsh peats from northern Seward Peninsula are plotted in Fig. 2.

\section{Results: lower storm levels graded to lower sea levels}

Former sea level datum planes were obtained from a cutbank exposure on Lopp Lagoon within the oldest depositional unit of the Wales complex (Fig. 3a,b). This section also establishes a minimum limiting age of 2000 cal BC for the development of the spit platform underlying the beach ridge facies. During $1700-1100 \mathrm{cal} \mathrm{BC}$, a stabilized surface $1 \mathrm{~m}$ below present MHHW was buried by thick storm overwash sand. A salt marsh formed from $800 \mathrm{cal} \mathrm{BC}$ to AD 1, 
with repeated phases of sand deposition due to wind or storm overwash, and produced a 50 -cm-thick peat and interbedded sand beds. Peat formation co-occurs with the progradation of Unit I on the Wales ridges and the onset of Unit II dunes that stabilized by $600-$ 950 cal AD (Fig. 3b) as Unit III was added. A shift in storm regimes during the Little Ice Age (1300-1800 AD, cf. Mason, 1999) led to the erosion of older portions of the Wales complex and the re-deposition of sand atop the lagoon margin, producing Unit IV.

Another datum for paleo-sea level in the Chukchi Sea was uncovered in the literature. Brown and Sellmann (1966) describe a peat $1.5 \mathrm{~m}$ below surface on a barrier island south of Point Barrow that is capped by an apparently storm-deposited coarse sand. The peat dates to $4570 \pm 130 \mathrm{BP}$ (I-1869), 3641-2905 cal BC. This paleo-sea level plane correlates with a $-1.5 \mathrm{~m}$ marsh peat along Cowpack lagoon (Jordan and Mason, $1999)$ growing $3787-3521$ cal BC ( $4870 \pm \mathrm{BP}$, Beta80204).

Three widely separated localities from Kotzebue to Point Barrow contain evidence of storm events graded to a lower sea level. A $1.5-\mathrm{km}$-long cutbank cross-cuts Cape Espenberg, $150 \mathrm{~km}$ northeast of Wales, at the entry to Kotzebue Sound. The Espenberg spit is divisible into four chronostratigraphic units, defined by two prominent storm-produced erosional truncations (Mason and Jordan, 1993). Driftwood and shell dated to $1740-1410 \mathrm{cal}$ BC from several storm beds (Table 1) occur at 0.7-1.0 m above MHHW, considerably below present-day maximum storm surge elevation. A pronounced horizontal disconformity across Cape Espenberg (cf. Mason et al., 1997) indicates that storm intensity was as great or greater than present. From this, we conclude that the elevation of the paleo-storm beds must reflect an eustatic sea level 1-1.5 m lower than present. In southern Kotzebue Sound, at Deering, several backhoe trenches revealed storm emplaced gravels on a prograding spit containing driftwood dated to $2860 \pm 80$ BP (Beta113144), $1290-830 \mathrm{cal} \mathrm{BC}$, and $2230 \pm 60$ BP (Beta113147), 400-118 cal BC (Reanier et al., 1998, p. 21). The older sample lies $1.3 \mathrm{~m}$ above MHHW while the younger is $2.0 \mathrm{~m}$ above MHHW (Reanier et al., 1998, p. 10). Finally, $500 \mathrm{~km}$ to the north, driftwood dated 800-200 cal BC (Table 1) within the Point Barrow spit was 1.4-1.7 m above MHHW (Hume, 1965; Péwé and Church, 1962). Considering the present storm surge limit of $>3 \mathrm{~m}$ above MHHW, we argue that this and other older storm emplaced driftwood represent a lower sea level.

These new data points supplement the curve produced from the Shishmaref barrier island, lagoonal and deltaic marsh peats which indicate the cumulative averaged rate of sea level rise in the Chukchi Sea was very slow, $0.27 \mathrm{~mm}$ year $^{-1}$ (Jordan and Mason, 1999). Several different depositional environments were sampled which may account for some of the scatter in the plot displayed in Fig. 2, as noted above.

In addition, the sea level curve from the Chukchi Sea indicates that much of the late Holocene rise occurred during the last several hundred years, irresolvable within the two sigma range of most conventional $<300$ year radiocarbon ages. Several low $(-50$ $\mathrm{cm})$ data points from the early Medieval period (700-1200 AD) may mark significant shifts in sea level. Paleo-storm beach elevations parallel those from marsh peats and confirm that sea level remained $>1 \mathrm{~m}$ below present about 1200 years ago. Flood tide delta vertical accretion around $1000 \mathrm{AD}$ reflects stormdriven deposition and not eustatic sea level.

\section{Conclusions: implications for 21 st century global change}

Radiometrically dated salt marsh peats and storm facies (shell, driftwood) from across northwest Alaska record only a slight rise in eustatic sea level of $1.5 \mathrm{~m}$, ca. $0.3 \mathrm{~mm}$ year $^{-1}$ on average, during the last 6000 years. A eustatic response is indicated by the trendline through data points because the eastern shores of the Chukchi Sea are not subject to appreciable co-seismic effects or glacial isostasy. Short-term fluctuations of relative sea level are superimposed on this long-term trend as indicated by the spread of data points within and between coastal depositional environments (Fig. 2 ). Some of this variability is probably related to climatically controlled fluctuations of sea level that occur at decadal or centennial scales, although our data are too limited to relate excursions of relative sea level to specific climatic events or regimes.

Our eustatic sea level curve for the Chukchi Sea (Fig. 2) differs considerably from the initial model of Clark and Lingle (1979, Fig. 1), which proposed that sea level in this region was $4.5 \mathrm{~m}$ below present at 
$4000 \mathrm{BC}$, rose to a minor $(0.25-0.5 \mathrm{~m})$ high stand after $1000 \mathrm{BC}$, and then gradually declined to present levels (Zone III). However, our data confirm theoretical calculations that incorporate the west Antarctic retreat component and places northwest Alaska in Zone IV (Clark and Lingle, 1979, Fig. 14). This model suggests that regional sea level was about 1 $\mathrm{m}$ below present 5000 years ago. Although not mapped explicitly by Peltier (1999), our curve gains support from his calculations that indicate glacial isostatic adjustments on a global scale largely ceased by 5000 BP. Several factors may explain differences between predicted and data-constrained sea level curves for the Chukchi Sea.

First, recall that the Chukchi Sea lacks any longterm annual tide gauge data so that direct comparisons of 19th and 20th century trends are not possible. Nonetheless, our paleo-sea level curve may indicate a slower response than the average rate of 1 to $2 \mathrm{~mm}$ of annual sea level rise, retrodicted from over 130 stations, mostly in the northern hemisphere (Gornitz and Lebedeff, 1987; Gornitz, 1993). Several factors may be responsible: (a) the Chukchi Sea may not experience appreciable amounts of steric expansion due to its colder sea surface temperature; (b) geoidal affects may counter eustatic rise; (c) permafrost development may counter the effects of sea level rise, as hypothesized for the Colville and Yukon Deltas (Jorgenson and Ely, 1998). The effects of peat compaction, not explicitly considered here, should act to increase the rate of relative sea level rise by increasing subsidence. The gradual slope of our curve implies that compaction-induced subsidence is minimal.

In any event, the rate of sea level rise for the Chukchi Sea falls considerably below that of barrier islands and marshes on the passive margin of North America (van de Plassche, 2000; Varekamp and Thomas, 1998), as well as other threatened low-lying areas (cf. various in Warrick et al., 1993). Geologic data suggest that, in the Chukchi Sea, storm frequency is correlated with colder rather than warmer climatic conditions (Mason and Jordan, 1993; Mason et al., 1996; Mason, 1999). Our data do not therefore support predictions of more frequent or intense coastal storms associated with atmospheric warming for this region. While this provides good news for disaster planners in northern Alaska, the uncertain response of frozen coasts to global climate change requires that we use caution in assessing their future evolution.

\section{Acknowledgements}

The Shared Beringian Heritage Project of the National Park Service funded our research from 1991 to 1995. Field research in 1996 at Wales was supported as part of a NSF grant to R.K. Harritt (Environmental and Natural Resources Institute, University of Alaska, Anchorage). This paper is a contribution to IGCP Project 367, Late Quaternary Coastal Records of Rapid Change.

\section{References}

Brigham-Grette, J., Hopkins, D.M., 1995. Emergent marine record and paleoclimate of the last interglaciation along the northwestern Alaskan coast. Quat. Res. 43, 159-173.

Brown, J., Sellmann, J.V., 1966. Radiocarbon dating of coastal peat, Barrow, Alaska. Science 153, 299-300.

Carter, R.W.G., 1988. Coastal Environments: An Introduction to the Physical, Ecological and Cultural Systems of Coastlines. Academic Press, New York.

Clark, J.A., Lingle, C.S., 1979. Predicted relative sea-level changes (18,000 Years B.P. to Present) caused by late-glacial retreat of the Antarctic ice sheet. Quat. Res. 11, 279-298.

Creager, J.S., McManus, D.A., 1966. Geology of the southeastern Chukchi Sea. In: Wilimovsky, N.J., Wolfe, J.N. (Eds.), Environment of the Cape Thompson region, Alaska. U.S. Atomic Energy Commission, Oakridge, pp. 755-786.

Douglas, B.C., 1991. Global sea level rise. J. Geophys. Res. 96 (C4), 6981-6992.

Dumond, D.E., 1998. The Hillside site, St. Lawrence Island, Alaska: An examination of collections from the 1930s. Univ. Oregon Anthro. Papers 55.

Dupré, W.R., 1982. Depositional environments of the Yukon delta, northeastern Bering Sea. Geol. Mijnbouw 61 (1), 63-70.

Dyke, A.S., Dale, J.E., McNeely, R.N., 1996. Marine molluscs as indicators environmental change in glaciated North America and Greenland during the 18,000 years. Geographie Physique Quaternaire 50, 125-184.

Eittreim, S., Grantz, A., Whitney, O.T., 1977. Tectonic imprints on sedimentary deposits in Hope Basin. In: Blean, K.M. (Ed.), The U.S. Geological Survey in Alaska: Accomplishments during 1976. U.S. Geol. Survey Circular, vol. 751, pp. 100-103.

Elias, S.A., Short, S.K., Phillips, R.L., 1992. Paleoecology of lateglacial peats from the Bering Land Bridge, Chukchi Sea shelf region, northwestern Alaska. Quat. Res. 38, 371-378.

Emery, K.O., Aubrey, D.G., 1991. Sea Levels, Land Levels and Tide Gauges. Springer-Verlag, New York. 
Faas, R.W., 1966. Paleoecology of an arctic estuary. Arctic 19, $343-348$.

Fujita, K., Cook, D.B., Hasegawa, H., Forsyth, D., Wetmiller, R., 1990. Seismicity and focal mechanisms of the Arctic region and the North American plate boundary in Asia. In: Grantz, A., Johnson, L., Sweeney, J.F. (Eds.), The Geology of North America: Volume 1. The Arctic Ocean Region. Geological Society of America, Boulder, pp. 79-100.

Gornitz, V., 1993. A comparison of differences between recent and late Holocene sea-level trends from eastern North America and other selected regions. In: Finkl, C.V. (Ed.), Holocene Cycles: Climate, Sea Levels, and Sedimentation. J. Coastal Res. Spec. Publ., vol. 17, pp. 287-298.

Gornitz, V., Lebedeff, S., 1987. Global sea level changes during the last century. In: Nummedal, D., Pilkey, O.H., Howard, J.D. (Eds.), Sea Level Changes and Coastal Evolution. Soc. Econ. Paleont. Miner. (SEPM) Spec. Publ., vol. 41, pp. 3-16.

Gornitz, V., Lebedeff, S., Hansen, J., 1982. Global sea-level trend in the past half-century. Science $215,1611-1614$.

Hamilton, T.D., Brigham-Grette, J., 1991. The last Interglaciation in Alaska: stratigraphy and paleoecology of potential sites. Quat. Int. $10-12,49-72$.

Hopkins, D.M., 1967. Quaternary marine transgressions in Alaska. In: Hopkins, D.M. (Ed.), The Bering Land Bridge. Stanford University Press, Palo Alto, CA, pp. 47-90.

Hume, J.D., 1965. Sea-level changes during the last 2000 years at Point Barrow, Alaska. Science 150, 1165-1166.

Hume, J.D., Schalk, M., 1967. Shoreline processes near Barrow, Alaska: a comparison of the normal and the catastrophic. Arctic $20,86-103$.

Jordan, J.W., Mason, O.K., 1999. A 5000 yr. record of intertidal peat stratigraphy and sea level rise from northwest Alaska. Quat. Int. 60, 37-47.

Jorgenson, T., Ely, C., 1998. Subtle topographic variation of ecosystems on the Yukon Delta: Implications for sea level rise. Program and Abstracts, 49th Arctic Science Conference. Am. Assoc. Adv. Science (AAAS), Arctic Division, Fairbanks, pp. 176-177.

Kaufman, D.S., Hopkins, D.M., 1986. Glacial history of the Seward Peninsula. In: Hamilton, T.D., Reed, K.M., Thorson, R.M. (Eds.), Glaciation in Alaska. Alaska Geological Society, Anchorage, pp. 51-78.

Mason, O.K., 1999. At the tail of Asia: late Holocene paleoclimatic records from northwest Alaska beach ridges. Proceedings, 1st International Conference on Biodiversity and Geoenvironmental Change, Seoul. Korean Quaternary Res. in 1999, pp. 9-40.

Mason, O.K., Jordan, J.W., 1993. Heightened North Pacific storminess and synchronous late Holocene erosion of northwest Alaska beach ridge complexes. Quat. Res. 40, 55-69.

Mason, O.K., Jordan, J.W., Plug, L., 1995. Late Holocene storm and sea-level history in the Chukchi Sea. J. Coastal Res., Spec. Issue $17,173-180$.

Mason, O.K., Salmon, D.K., Ludwig, S.L., 1996. The periodicity of storm surges in the Bering Sea region from 1898 to 1993, based on newspaper accounts. Clim. Change 34, 109-123.

Mason, O.K., Hopkins, D.M., Plug, L., 1997. Chronology and paleo-climate of storm-induced erosion and episodic dune growth across Cape Espenberg spit, Alaska, U.S.A. J. Coastal Res. 13 (3), 770-797.

McManus, D.A., Creager, J.S., 1984. Sea-level data for parts of the Bering-Chukchi shelves of Beringia from 19,000 to 10,000 $14 C$ yr B.P. Quat. Res. 21, 317-325.

Moore, G.W., 1960. Recent eustatic sea-level fluctuations recorded by arctic beach ridges. In: U.S. Geological Survey Research 1960 U.S. Geol. Survey Prof. Paper 400, B335-7.

Naidu, A.S., Gardner, G., 1988. Marine geology. In: Hameedi, M.J., Naidu, A.S. (Eds.), The Environment and Resources of the Southeastern Chukchi Sea, Outer Continental Shelf (OCS) Study, Mineral Management Study 87-0113, pp. 11-28.

Nichols, R.J., Leatherman, S.P., 1995. Global sea-level rise. In: Strzepek, K.M., Smith, J.B. (Eds.), As Climate Changes: International Impacts and Implications. Cambridge University Press, Cambridge, pp. 92-123.

Nelson, C.H., 1982. Late Pleistocene and Holocene sedimentation in deltaic and nondeltaic areas of the northeastern Bering continental shelf. Geol. Mijnbouw 61, 5-18.

Nelson, C.H., Creager, J.S., 1977. Displacement of Yukon-derived sediment from Bering Sea to Chukchi Sea during Holocene time. Geology 5, 141-145.

Peltier, W.R., 1999. Global sea level rise and glacial isostatic adjustment. Global Planet. Change 20, 93-123.

Péwé, T.L., Church, R.E., 1962. Age of the spit at Barrow, Alaska. Bull. Geol. Soc. Am. 73, 1287-1291.

Pirazzoli, P.A., 1991. World Atlas of Holocene Sea-Level Changes. Elsevier, Amsterdam.

Rainey, F.G., 1941. Eskimo prehistory: the Okvik site on the Punuk islands. Anthro. Papers, Am. Mus. Nat. Hist. 37 (4), $452-$ 569.

Reanier, R.E., Sheehan, G.W., Jensen, A.M., 1998. Report of 1997 field discoveries city of Deering Village Safe Water Cultural Resources Project. Report to Ukpeagvik Inupiaq Corporation Real Estate Division, Barrow.

Roep, T.B., 1986. Sea-level markers in coastal barrier sands: examples from the North Sea coast. In: van de Plassche, O. (Ed.), Sea Level Research: A Manual for the Collection and Evaluation of Data. Geo Books, London, pp. 97-128.

Sedinger, J., 1998. Coastal systems. In: Weller, G.A., Anderson, P.A. (Eds.), Implications of Global Change in Alaska and the Bering Sea region. Proceedings of a workshop, June 1997, Center for Global Change and Arctic System Research. Geophysical Institute, University of Alaska, pp. 105-114.

Shennan, I., Tooley, M.J., Davis, M.J., Haggart, A., 1983. Analysis and interpretation of Holocene sea-level data. Nature 302, 404-410.

Stuiver, M., et al., 1998. IntCa198 radiocarbon age calibration, 24,000-0 cal bp. Radiocarbon 40 (3), 1041-1084.

Taylor, N., Stone, G.W., 1996. Beach ridges: a review. J. Coastal Res. 12, 612-621.

Thenhaus, P.C., et al., 1982. Probabilistic estimates of maximum seismic horizontal ground motion on rock in Alaska and the adjacent Outer Continental Shelf. U.S. Geological Survey in Alaska: Accomplishments During 1980. U.S. Geol. Surv. Circ. $844,5-8$.

Trimble, D.A., Robinson, S.W., 1989. U.S. Geological Survey, 
Menlo Park, California radiocarbon measurements IV. Radiocarbon 31, 69-84.

van de Plassche, O. (Ed.), 1986. Sea Level Research: A Manual for the Collection and Evaluation of Data. Geo Books, London. van de Plassche, O., 2000. North Atlantic climate-ocean variations and sea level in Long Island Sound, Connecticut, since $500 \mathrm{cal}$ yr A.D. Quat. Res. 53, 89-97.

van de Plassche, O., van Der Borg, K., de Jong, A.F.M., 1998. Sea level-climate correlation during the past 1400 yr. Geology 26, 319-322.

Varekamp, J.C., Thomas, E., 1998. Climate change and the rise and fall of sea level over the millennium. Eos 79 (6), 69, 74-75.
Warrick, R.A., Oerlemans, H., 1990. Sea level rise. In: Houghton, J.T., Jenkins, G.J., Ephraums, J.J. (Eds.), Climate Change: The IPCC Scientific Assessment. Cambridge University Press, Cambridge, pp. 257-282.

Warrick, R.A., Barrow, E.M., Wigley, T.M.L. (Eds.), 1993. Climate and Sea Level Change: Observations, Projections, Implications. Cambridge University Press, Cambridge.

Wigley, T.M.L., Raper, S.C.B., 1992. Implications for climate and sea level of revised IPCC emissions scenarios. Nature 357, $293-300$. 